Diyala Journal of Engineering Sciences

Journal homepage: https://jes.info/index.php/djes

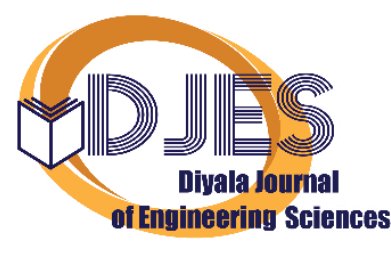

ISSN: 1999-8716 (Print); 2616-6909 (Online)

\title{
Behavior of Reactive Powder Concrete Beams Exposed to Fire
}

\author{
Mahmoud Ahmed Ali abdelrahim ${ }^{1 *}$, Aboelwafa Elthakeb ${ }^{1}$, Usama Mohamed ${ }^{2}$ and Mohamed Taha Noaman ${ }^{1}$ \\ ${ }^{1}$ Department of Civil Engineering, Faculty of Engineering, Al-Azhar University, Egypt \\ ${ }^{2}$ Department of Civil Engineering, Faculty of Engineering, Minia University, Egypt
}

\section{ARTICLE INFO ABSTRACT}

Article history:

Received 23 September 2021

Accepted 6 December 2021

\section{Keywords:}

Exposed to fire

Beams

Fire flame

Cracking

Steel fibers

Reactive powder concrete beams

\begin{abstract}
In this paper, the effect of direct fire flame and steel fiber ratio on some mechanical properties and behavior of the relationship between load and deflection of rectangular reinforced concrete beams under the influence of fire exposure was studied. Concrete specimens were exposed to fire at temperatures ranging from $\left(25-400{ }^{\circ} \mathrm{C}\right)$. Three temperature levels of $\left(200,300,400{ }^{\circ} \mathrm{C}\right)$ where chosen for exposure duration of 2.0 hours. After conducting the test, it was found that increasing the proportion of steel fibers in percentages $0.5 \%$ to $1 \%$ and $1.5 \%$ decreases the mid-span deflection at service load by $33 \%, 50 \%$ and 37.5 and increases the ultimate load by $36.36 \%, 41.6 \%$ and $53 \%$ respectively. After the beams are exposed to fire, it was noticed that the maximum crack width increases with increasing fire temperature.
\end{abstract}

\section{Introduction}

Reactive Powder Concrete (RPC) One of the latest products of the new generation of concrete It has high cement content and low water content as well as fine sand and silica dust. The results showed that the resistance of RPC samples decreases when the high temperature increases. At $400{ }^{\circ} \mathrm{C}$, the losses in compressive strength and split tensile strength were $77.78 \%$ and $85 \%$, respectively. [1]. Studied the effect of elevated temperatures on performance of RCC beams. Results revealed robust performance up to $550^{\circ} \mathrm{C}$. The drop in flexural strength $\&$ other parameters was noticeable but not alarming up to $750^{\circ} \mathrm{C}$. Around $950^{\circ} \mathrm{C}$, the RCC members lost their fidelity on all counts [3]. Investigated four hybrid-fiber reinforced RPC beams protected with fire insulation exposed to fire flame. They note that the failure of the reinforced RPC beams was due to a fracture in the longitudinal armature caused by direct exposure to fire after failure of the fire insulator on the RPC beam [4].
Studied the phenomenon of fragmentation of Ultra High-Performance Concrete (UHPC) beams when exposed to high temperatures. The results showed that the fragmentation phenomenon was affected by the loading level. Under the same loading conditions, the fragmentation of beams containing steel fibers was $4 \%$ less than that of beams with a content of $2 \%$ [5]. Several results $(6,7,8,9$, and 10) showed a deterioration in the properties of concrete under exposure to high temperatures. The degree of deterioration was affected by the type of aggregate and concrete used.

\section{Experimental program}

\subsection{Materials \\ 2.1.1. Cement}

Portland cement grade [CEM I 52.5N] was used. [11] The properties of the cement used are in accordance with the Egyptian Standard Specifications E.S.S. 47561/2013.

\footnotetext{
* Corresponding author.

E-mail address: mahmoudarahim@yahoo.com

DOI: $10.24237 /$ djes.2021.14401
}

This work is licensed under a Creative Commons Attribution 4.0 International License. 


\subsubsection{Fine sand}

Very fine sand used according to the Egyptian Specification (E.S.S 1109/2008 requirements) [12]. Its small maximum nominal size $(0.6 \mathrm{~mm})$. Its grading is shown in Table (1).

Table 1: Classification of sand used according to (E.S.S. 1109/2008)

\begin{tabular}{lcccc}
\hline Sieve No. & No.30 & No.50 & No.100 & No.200 \\
\hline passing \% & 100 & 58 & 7 & 0.7 \\
\hline
\end{tabular}

\subsubsection{Silica fume}

In this study, silica fume was used as a mineral mixture added to RPC concrete.

\subsubsection{Steel fibers}

To increase RPC ductility, a steel fiber hook end is used. The steel fibers were $50 \mathrm{~mm}$ in length and diameter $0.5 \mathrm{~mm}$ density of 7800 $\mathrm{kg} / \mathrm{m}^{3}$, and maximum tensile strength of 1200 $\mathrm{MPa}$.

\subsubsection{Water}

Pure water was used to mix and treat concrete.

\subsubsection{Super-plasticizer}

A commercial name (Sikament 163) was used. The properties of the admixture correspond to with ASTM C494-Type A and F [13].

\subsection{Concrete mix}

Concrete was mixed and stirred in a large capacity mixer $0.1 \mathrm{~m} 3$. The details of concrete compositions together with the resulting cube strength after 28 days are shown in Table 2 .

Table 2: Details of concrete mix.

\begin{tabular}{|c|c|c|c|c|c|c|c|}
\hline Mix & $\begin{array}{l}\text { Cement } \\
\mathrm{kg} / \mathrm{m}^{3}\end{array}$ & $\begin{array}{c}\text { Fine sand } \\
\mathrm{kg} / \mathrm{m}^{3}\end{array}$ & Silica fume $\%$ & $\begin{array}{c}\text { Steel fiber } \\
\% \\
\end{array}$ & $\mathrm{~W} / \mathrm{C} \%$ & $\begin{array}{c}\text { Super- } \\
\text { plasticizer \% }\end{array}$ & $\begin{array}{c}\text { fcu } \\
{[\mathrm{MPa}]}\end{array}$ \\
\hline R0 & 800 & 1100 & $20 \%$ & $0 \%$ & $20 \%$ & $4 \%$ & 90 \\
\hline R0.5 & 800 & 1100 & $20 \%$ & $0.5 \%$ & $20 \%$ & $4 \%$ & 98 \\
\hline R1 & 800 & 1100 & $20 \%$ & $1 \%$ & $20 \%$ & $4 \%$ & 103 \\
\hline $\mathrm{R} 1.5$ & 800 & 1100 & $20 \%$ & $1.5 \%$ & $20 \%$ & $4 \%$ & 110 \\
\hline
\end{tabular}

\subsection{Details of beams}

Twenty reinforced concrete beams each with nominal dimensions of $1.70 \mathrm{~m}$ overall length, $0.20 \mathrm{~m}$ depth and $0.120 \mathrm{~m}$ width as shown in Fig. (1). All beams were provided with $3-\varnothing 10 \mathrm{~mm}$ bottom reinforcement and $2-\varnothing 8 \mathrm{~mm}$ top reinforcement. The tested beams were divided to five main groups (G1, G2, G3, G4 and G5). Groups G1, G2, G3, and G4 each consist of four beams with different steel fiber ratios $(0 \%, 0.5 \%, 1 \%$ and1.5\%). Group G5 consist of four beams all with steel fiber ratio of $1 \%$. The first main group named $(\mathrm{G} 1, \mathrm{G} 2, \mathrm{G} 3$ and G4) were provided with $\varnothing 6 \mathrm{~mm}$ stirrup every $100 \mathrm{~mm}$ to study their flexural behavior at different temperature levels, and to prevent shear failure. The second main group named G5 provided with $\varnothing 6 \mathrm{~mm}$ stirrup every $160 \mathrm{~mm}$ to study their shear behavior at different temperature levels. Beams of Group G1 are considered the reference beams. The first three columns in Table (3) summarize the beam groups and the applied temperatures. 

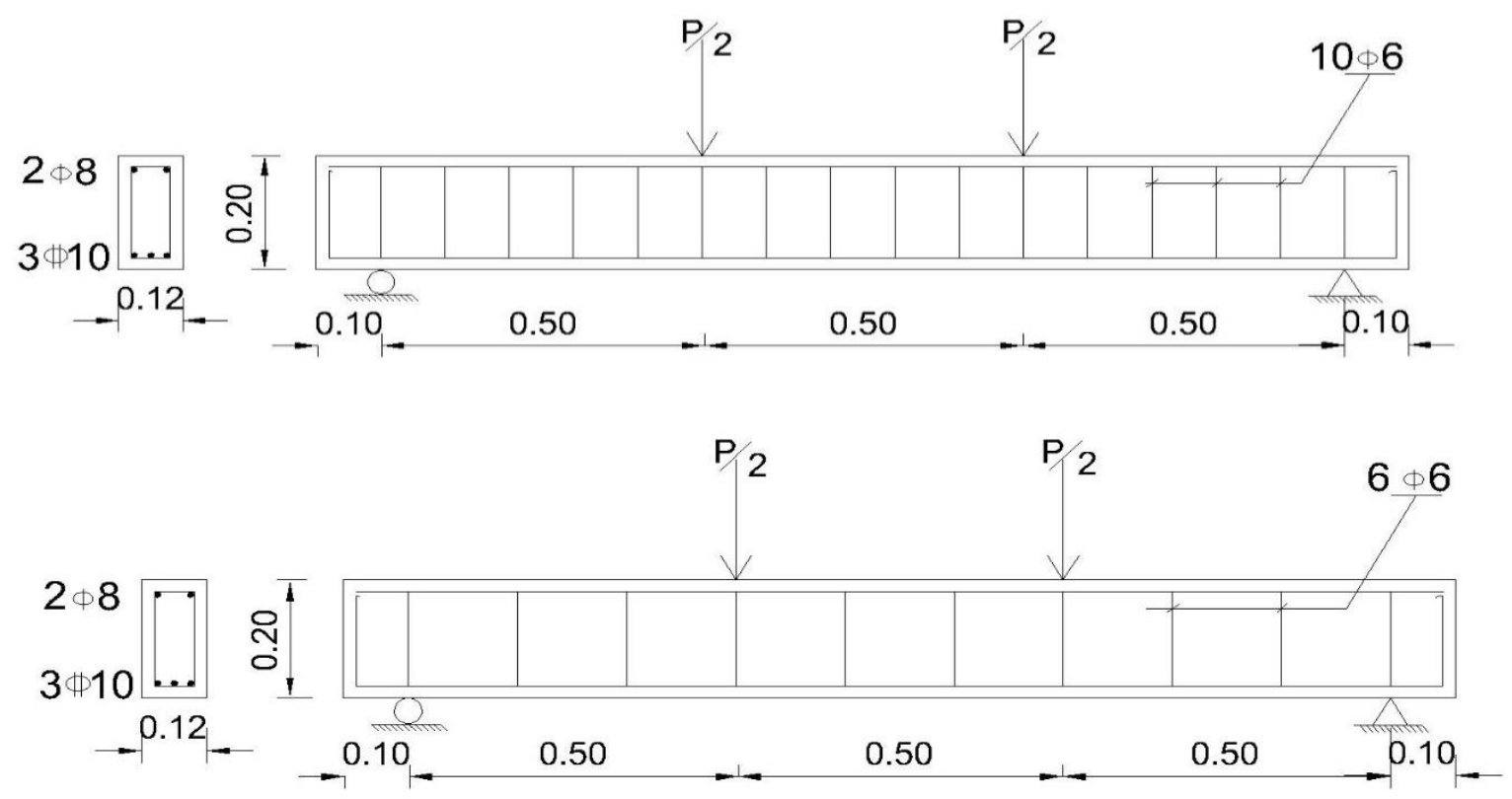

Figure 1. Details of the tested beams (all dimensions are its m)

\subsection{Test methods}

The test was carried out in two stages: in the first stage of the test, each beam is positioned simply supported by a two-point load the beam was gradually loaded static load until reaching the service load worth 3.25 tons which was obtained by reference beam test the apparent extension between the two loading points is $500 \mathrm{~mm}$ as shown in Figure (1). to measure the maximum deflection of the beam under load, a dial gage was placed in the mid span so that the head of dial gage touches the bottom face of the beam. The corresponding deviation was recorded for the service load, then the fire furnace was operated at the required temperature then the beam was exposed to fire from three sides, from the bottom and from both sides until the failure of the sample or reaching the maximum test time of two hours, as shown in Figure (2). A thermo cable and Digital temperature indicator was used to measure different temperatures. Two wires of different metals are connected together at the intersection, as shown in Figure (2). then the sample was left in the air for 24 hours, then the loading was completed until the sample failed the deviation corresponding to the maximum load was recorded.

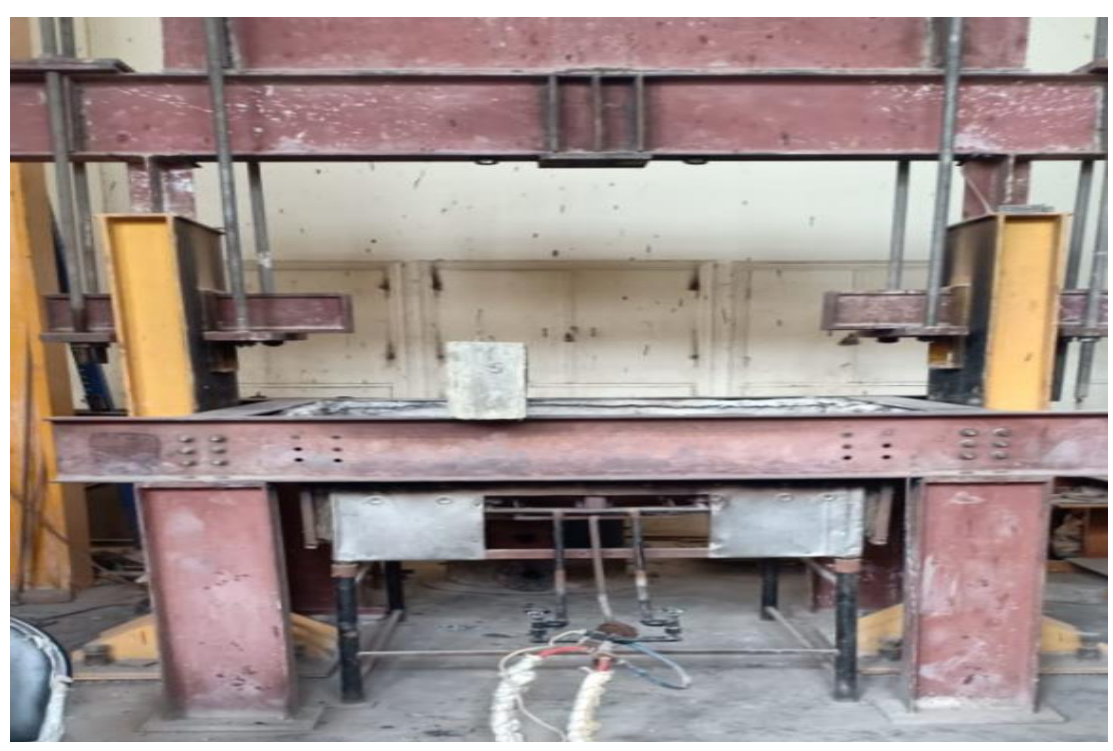



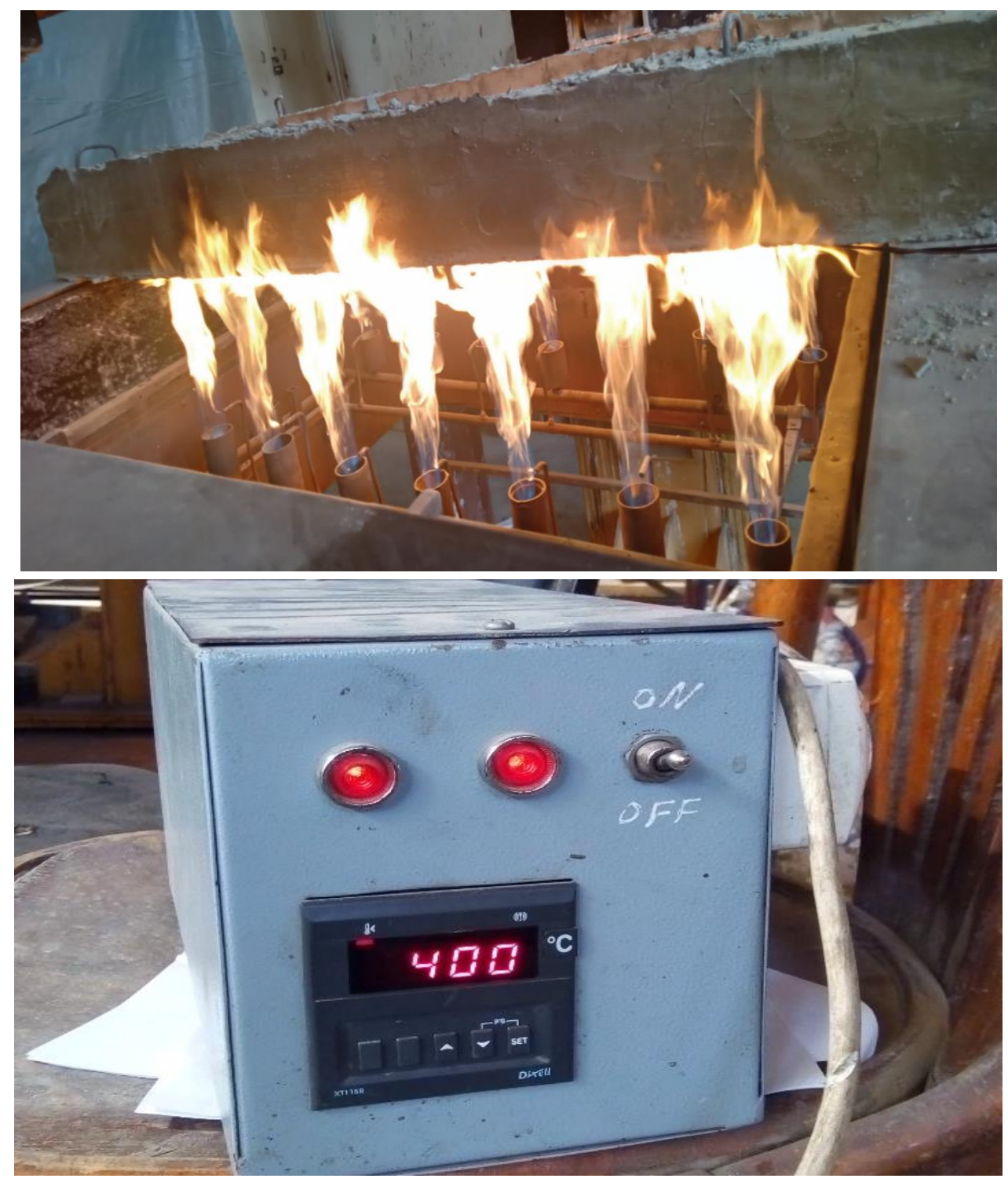

Figure 2. Tested samples and furnace used

\section{Results and discussion}

3-1 Crack patterns and mode of failure at room temperature

The reference beams such as R0 showed the typical mode of failure under flexural load. The cracks started in the tension zone within the middle third of the beam. The cracks were then propagated along the depth of the beam. It can be noticed for beams with steel fibers played a major role, by observing the mode of failure for RPC beams container with steel fibers and without fibers. The final failure occurred due to the formed two main inclined cracks and crushed of concrete under the point of loading as shown in Fig. (3).

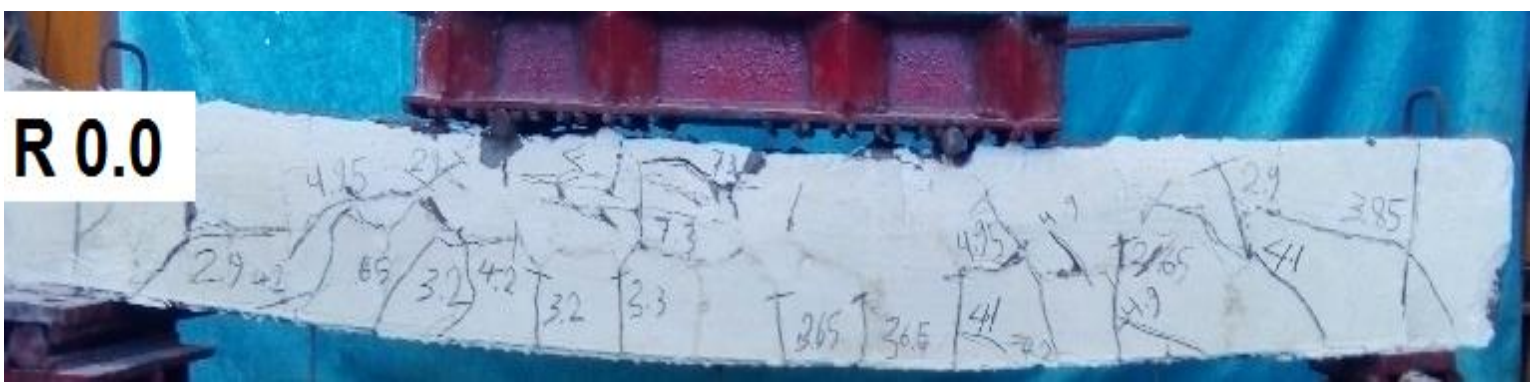




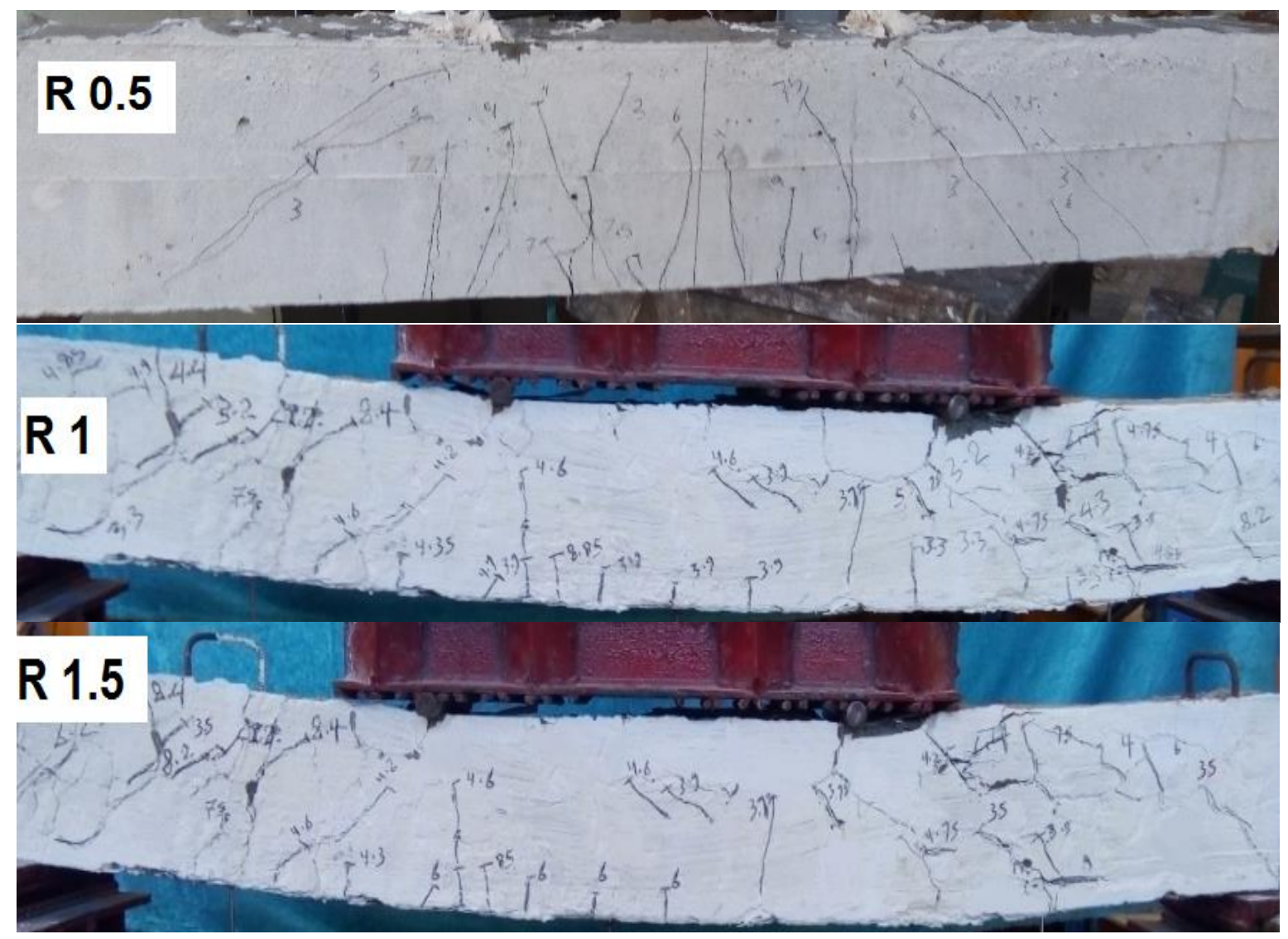

Figure 3. Mode of failure of beam at group 1 (G1)

\section{3-2 Crack patterns and mode of failure at different temperature exposures}

Based on the results of the tests, the first crack load and the corresponding deflection are shown, as well as the maximum load and the corresponding deflection, after operating the fire furnace and direct exposure to fire for two hours as shown in table 3. Having been exposed to fire before failure, it showed that cracks had started and spread along the beam. Concrete cracking is observed at different locations. Figures (4 to 7) shows the crack patterns and mode of failure at different temperature exposures.

Table 3: Results of the tests beams

\begin{tabular}{|c|c|c|c|c|c|c|}
\hline $\begin{array}{c}\text { Group } \\
\text { No. }\end{array}$ & $\begin{array}{c}\text { Mix } \\
\text { No }\end{array}$ & $\begin{array}{c}\text { Temperatu } \\
\text { re of fire } \\
\text { flame } \\
\left({ }^{\circ} \mathrm{C}\right) \\
\end{array}$ & $\begin{array}{c}\text { cracking } \\
\text { load pcr (t) }\end{array}$ & $\begin{array}{c}\text { Ultimate } \\
\text { load pu (t) }\end{array}$ & $\begin{array}{c}\text { deflection } \\
\text { at cracking } \\
\text { load } \delta \text { pcr } \\
(\mathrm{mm})\end{array}$ & $\begin{array}{c}\text { deflection } \\
\text { at ultimate } \\
\text { load } \delta p u \\
(\mathrm{~mm})\end{array}$ \\
\hline \multirow{4}{*}{ G1 } & Ro & \multirow{4}{*}{25} & 2.9 & 7.3 & 6 & 32 \\
\hline & R0.5 & & 3 & 7.7 & 4.6 & 27 \\
\hline & $\mathrm{R} 1$ & & 3.2 & 8.85 & 4 & 28 \\
\hline & R1.5 & & 3.5 & 9 & 4 & 27 \\
\hline \multirow{4}{*}{ G2 } & Ro & \multirow{4}{*}{200} & 1.1 & 4.4 & 12 & 37 \\
\hline & R0.5 & & 1.6 & 4.81 & 10 & 34 \\
\hline & $\mathrm{R} 1$ & & 1.8 & 5.5 & 9 & 30 \\
\hline & $\mathrm{R} 1.5$ & & 1.92 & 6 & 8 & 27 \\
\hline \multirow{4}{*}{ G3 } & Ro & \multirow{4}{*}{300} & 0.9 & 3 & 14 & 44 \\
\hline & R0.5 & & 1.1 & 3.5 & 11 & 40 \\
\hline & $\mathrm{R} 1$ & & 1.65 & 3.9 & 9 & 36 \\
\hline & R1.5 & & 1.86 & 4.25 & 7 & 31 \\
\hline \multirow{4}{*}{ G4 } & Ro & \multirow{4}{*}{400} & 0.83 & 2 & 16 & 50 \\
\hline & R0.5 & & 0.9 & 2.2 & 14 & 46 \\
\hline & $\mathrm{R} 1$ & & 1 & 2.65 & 12 & 44 \\
\hline & R1.5 & & 1.1 & 3.06 & 10 & 35 \\
\hline \multirow{4}{*}{ G5 } & \multirow{4}{*}{$\mathbf{R} \mathbf{1}$} & 25 & 2 & 6.65 & 4 & 29 \\
\hline & & 200 & 1.25 & 3.7 & 5 & 32 \\
\hline & & 300 & 1.2 & 2.6 & 8 & 35 \\
\hline & & 400 & 0.95 & 2.1 & 10 & 42 \\
\hline
\end{tabular}




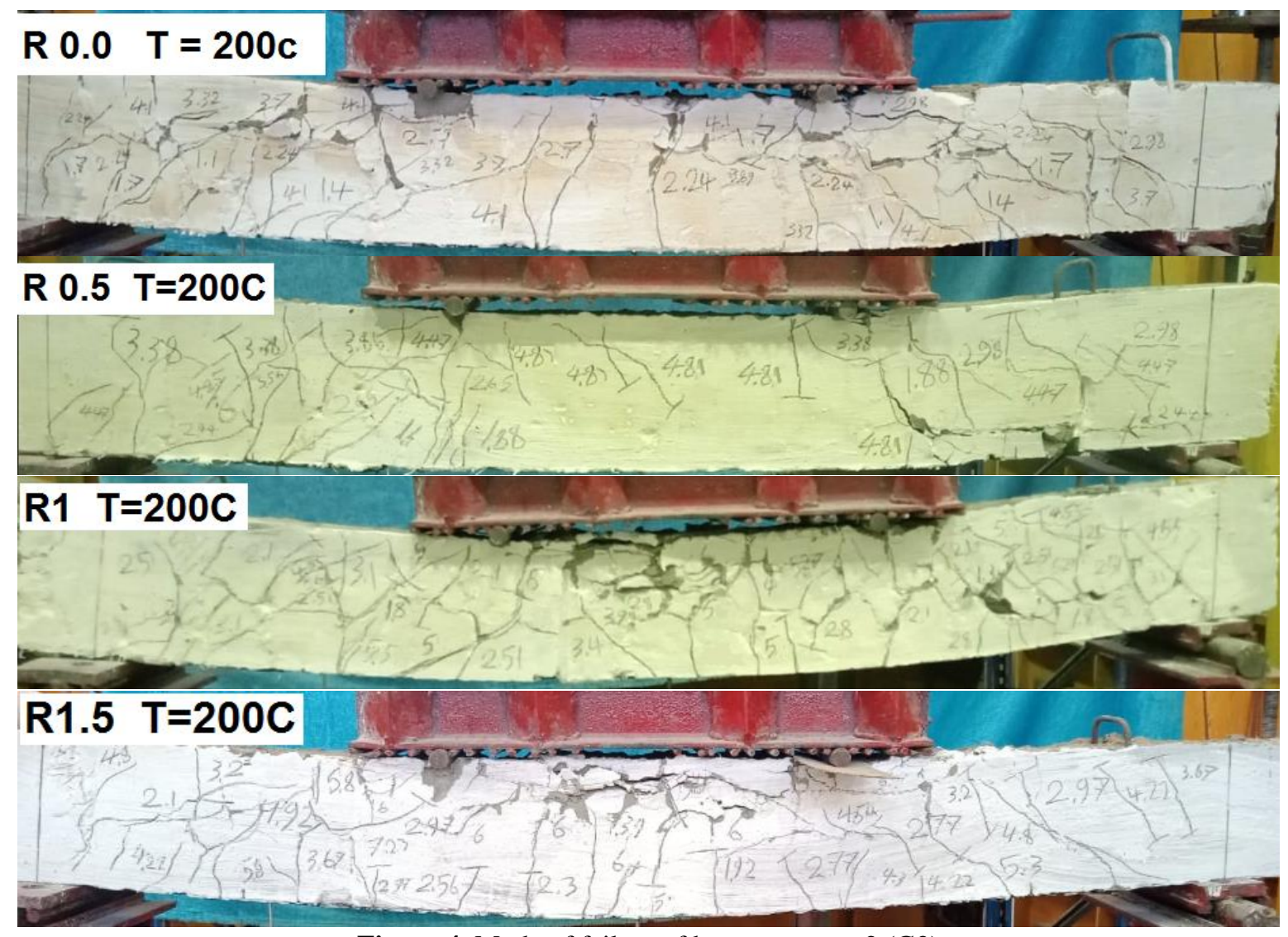

Figure 4. Mode of failure of beam at group 2 (G2)

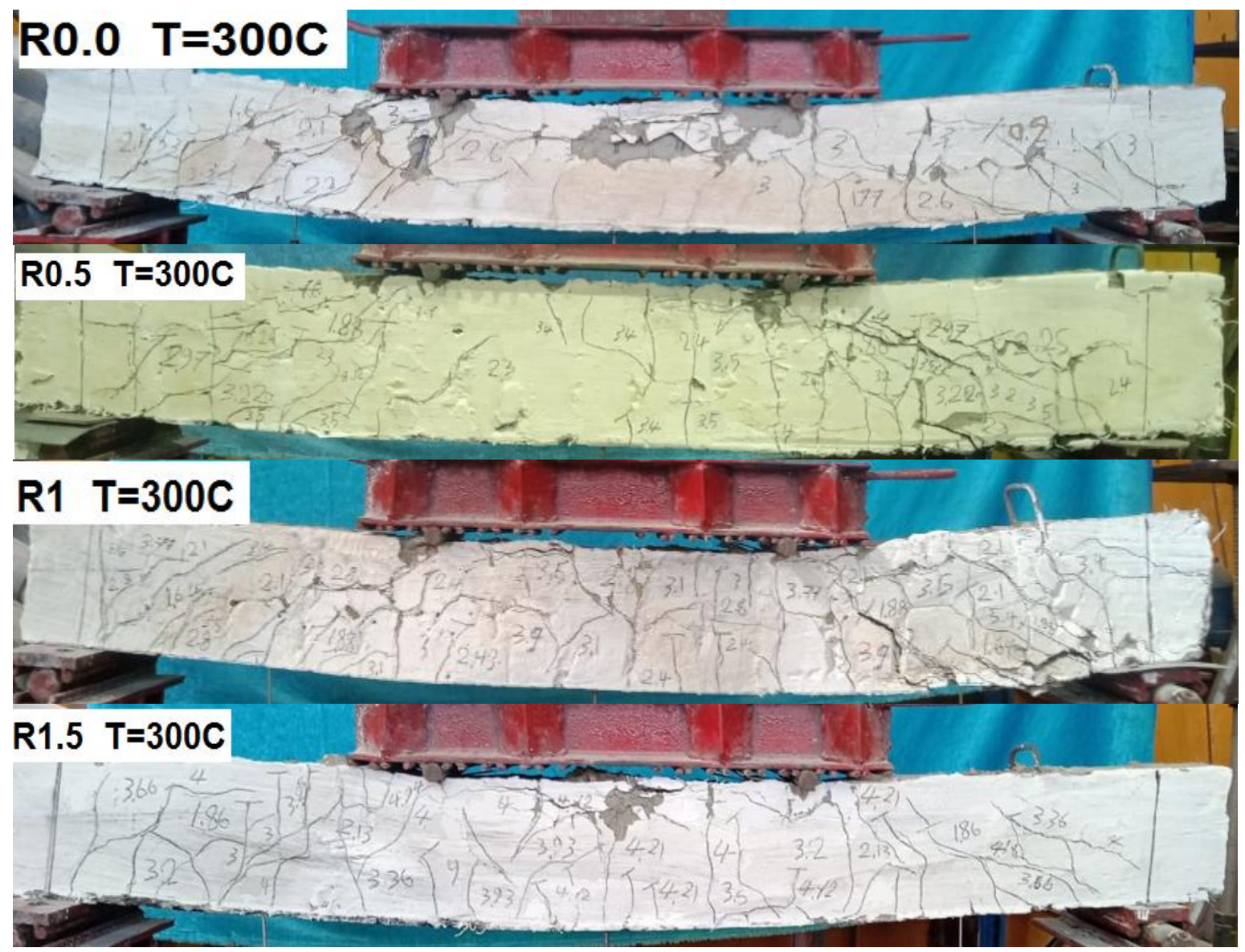

Figure 5. Mode of failure of beam at group 3 (G3) 


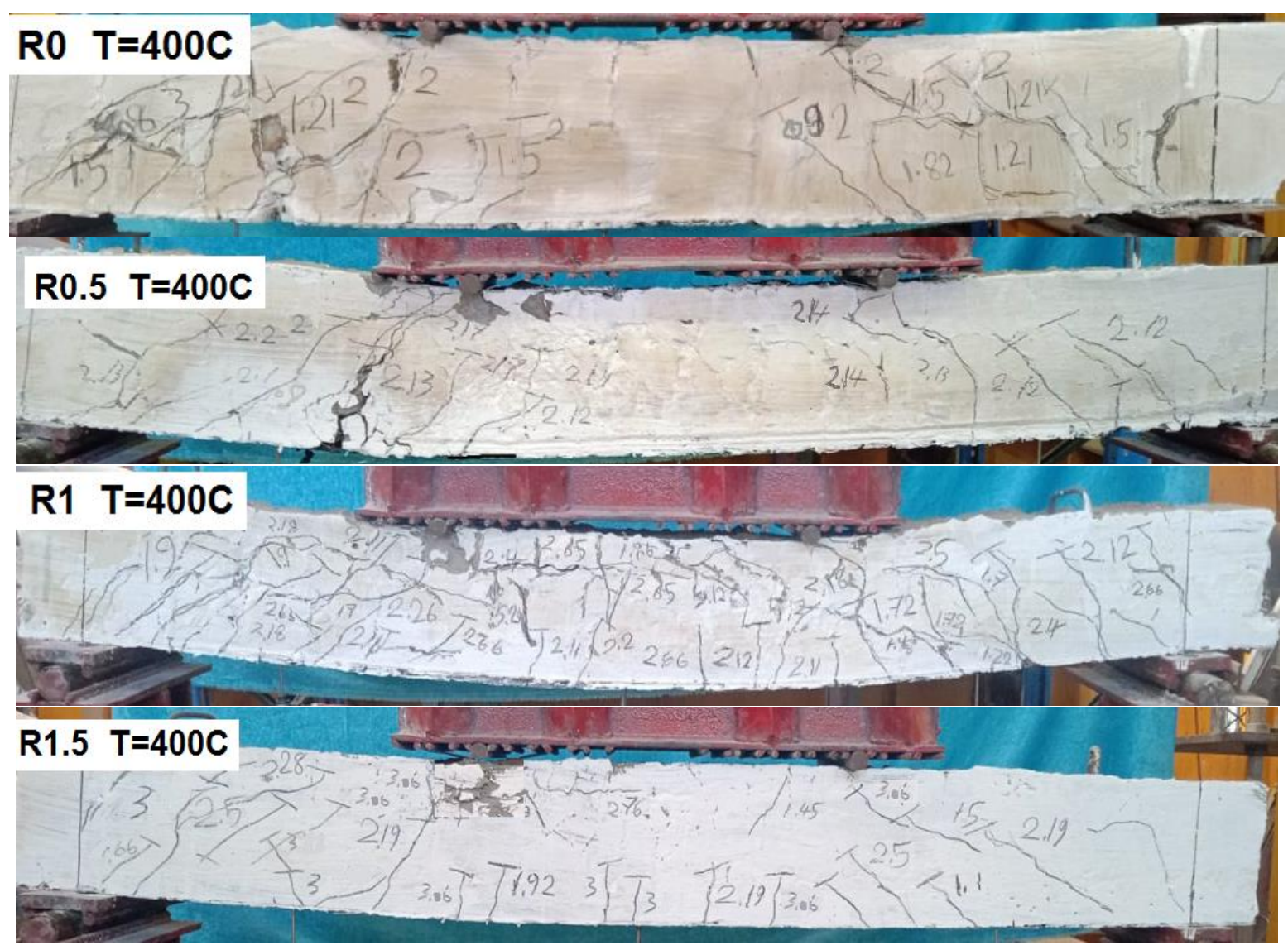

Figure 6. Mode of failure of beam at group 4 (G4)

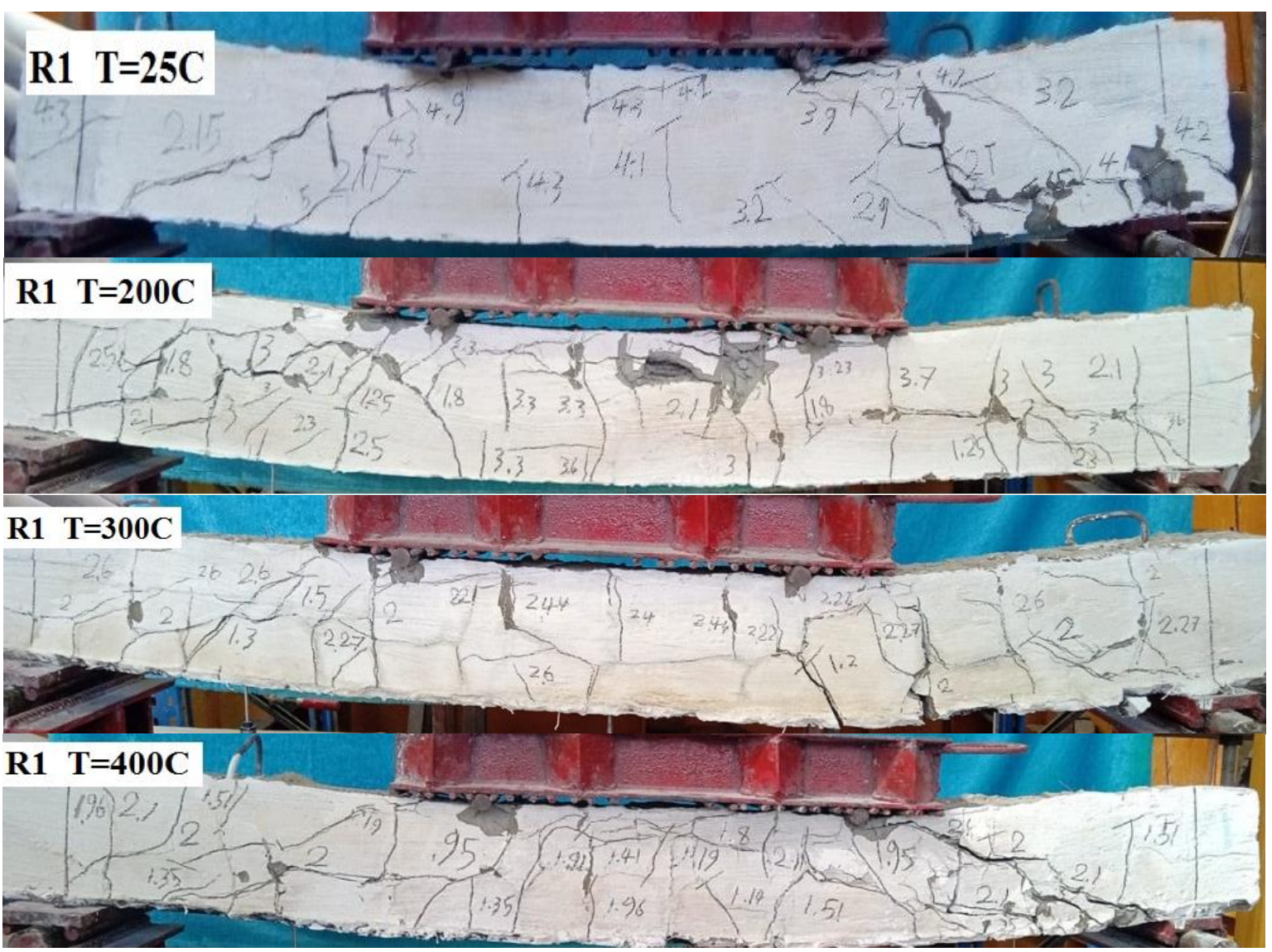

Figure 7. Mode of failure of beam at group 5 (G5) 


\subsection{The load-deflection relationship of beam at room temperature}

The load is tested against the deflection of the booster reference RPC beams tested under two-point loading until the failure as shown in Figure (8). Effect of increasing steel fiber content on load-deflection curve is very clear in Fig. (8), as the steel fibers ratio increases the curve becomes stiffer. The largest difference is between beam R0 (beam with zero steel fibers) and beams R1.5 (beams with high ratios of steel fibers). It is generally concluded that as steel fiber content increases the failure load increases too (using $1.5 \%$ steel fiber ratio increases failure load by $23.3 \%$ ).

\subsection{The load-deflection relationship of beam after different temperature exposures}

The deflection at the end of the heating time is displayed for all beams in table (3). When the beams are exposed to fire in the second stage of the test, a significant increase in deflection can be observed resulting from decreasing the bending strength in the beam and thus increasing the deflection. This is shown in the figures from 9 to 14 .

\subsection{Fire Resistance of reinforced RPC beams}

Regarding the effect of temperature on the final load, Fig. (15 and 16) shows the decrease in the final load due to the increase in temperature.

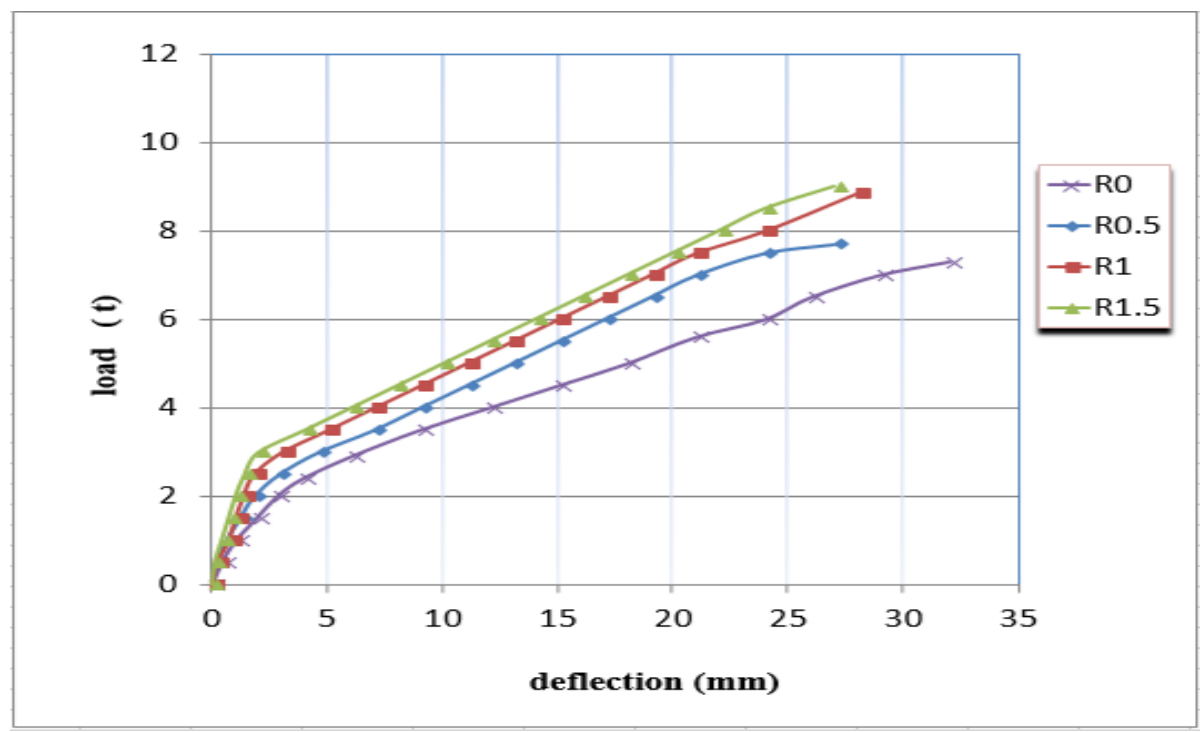

Figure 8. Load-deflection of beam at Room Temperature

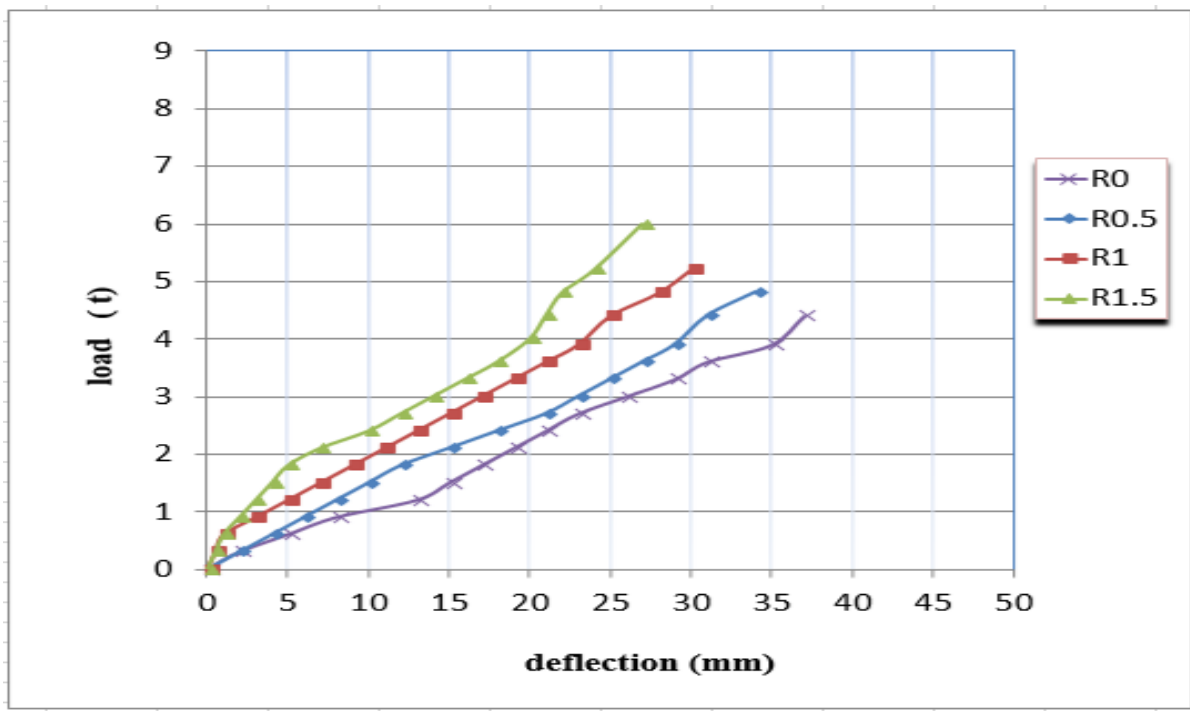

Figure 9. Load-deflection of beams at group 2 (G2) 


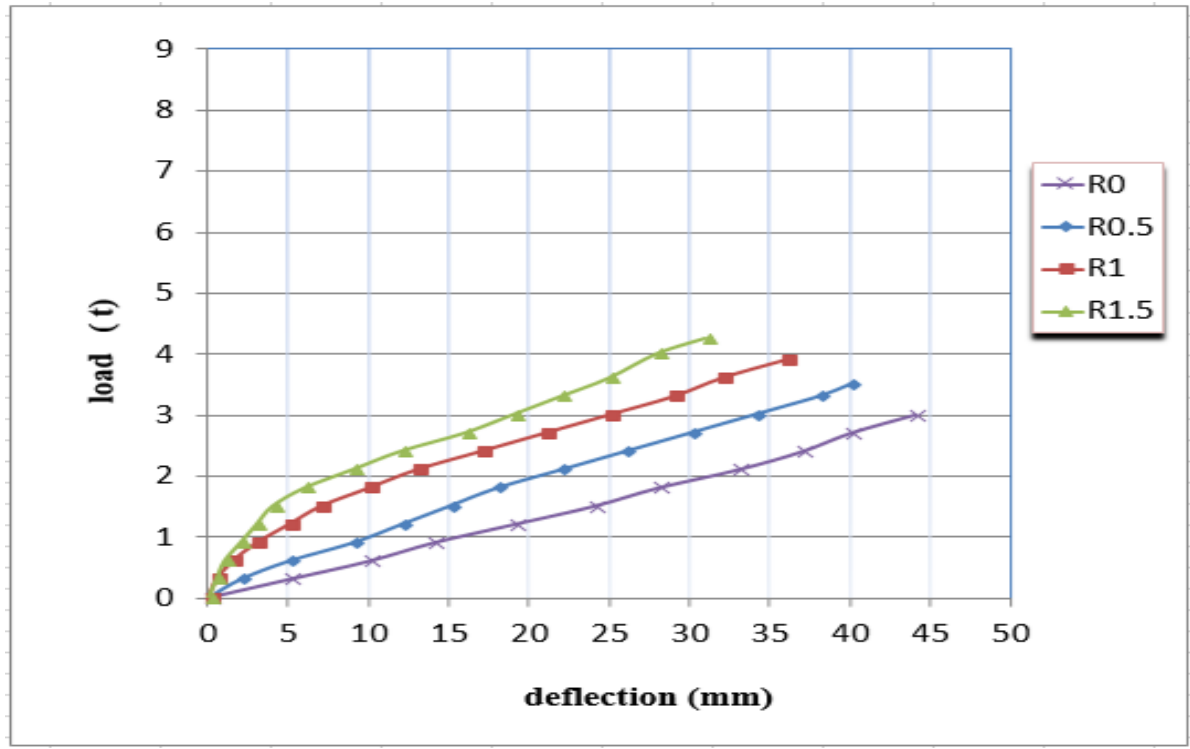

Figure 10. Load-deflection of beams at group 3 (G3)

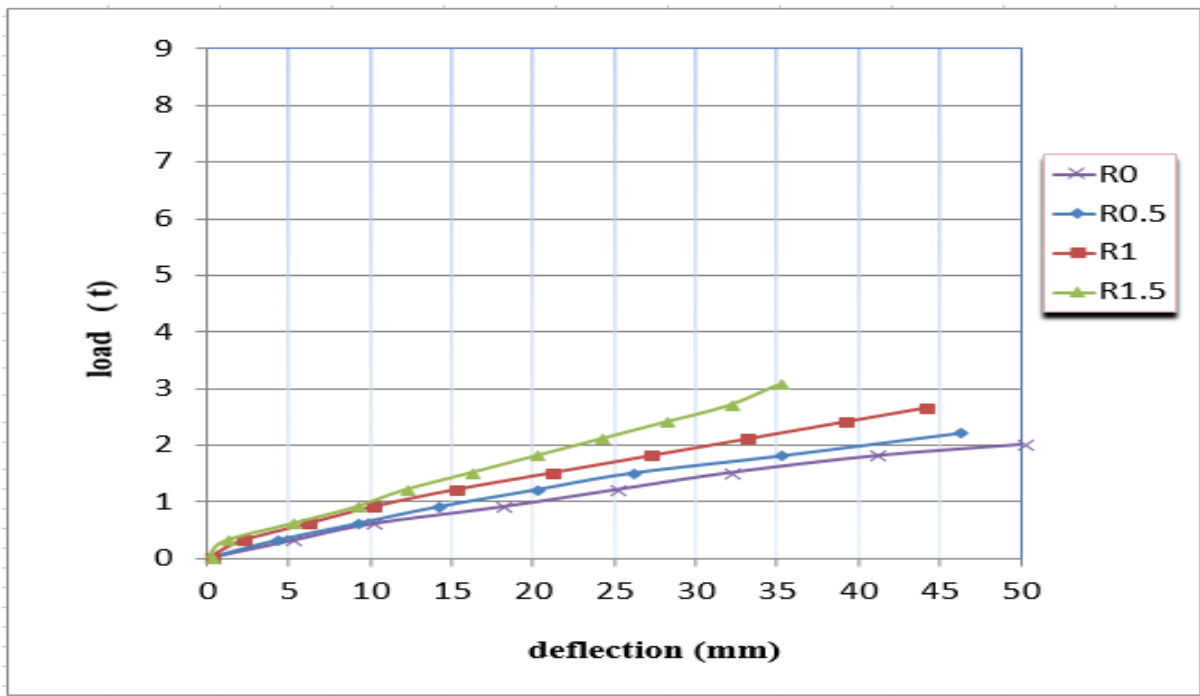

Figure 11. Load-deflection of beams at group 4 (G4)

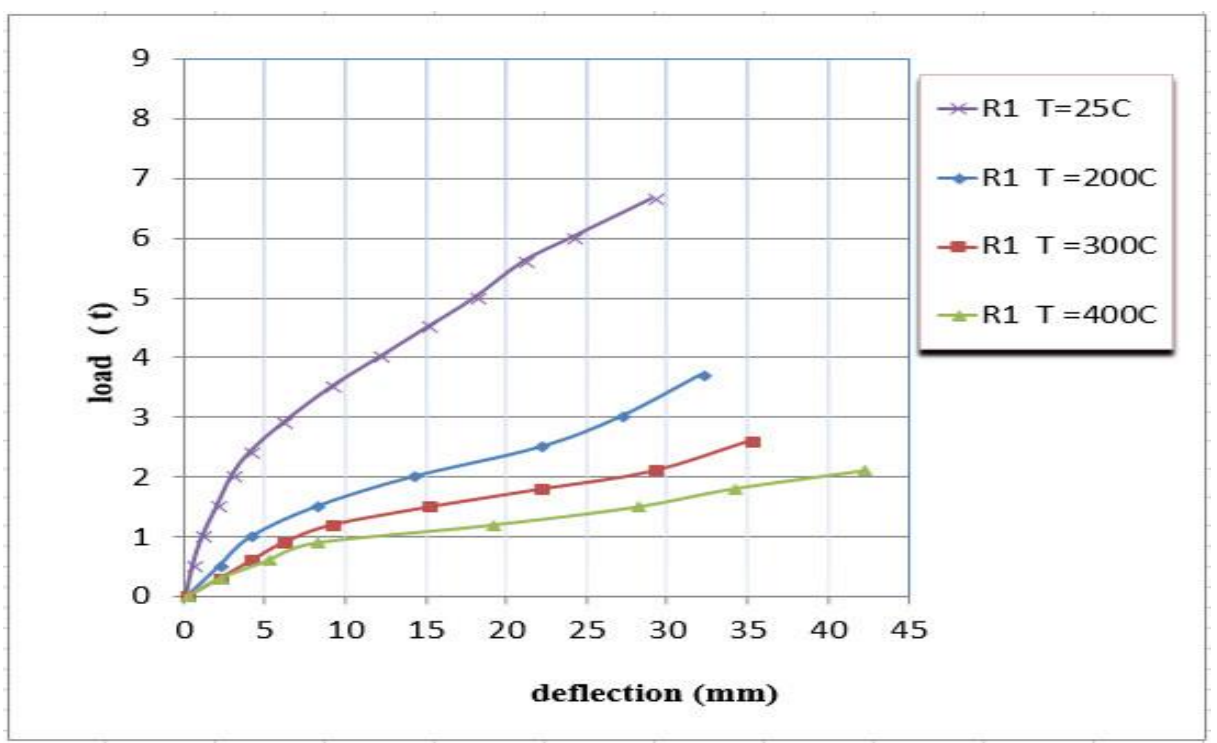

Figure 12. Load-deflection of beams at group 5 (G5) 


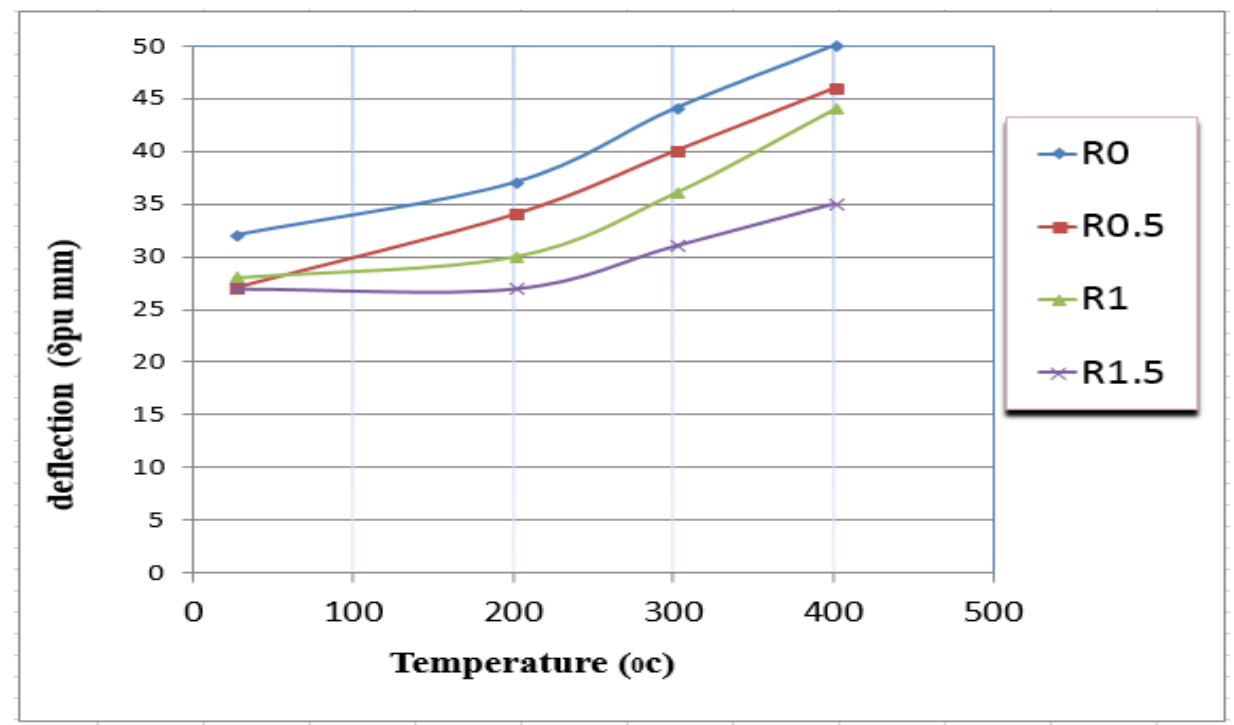

Figure 13. Effect of steel fibers with different volume fractions on mid span Deflection-temperature curve of RPC beams from group (1-4)

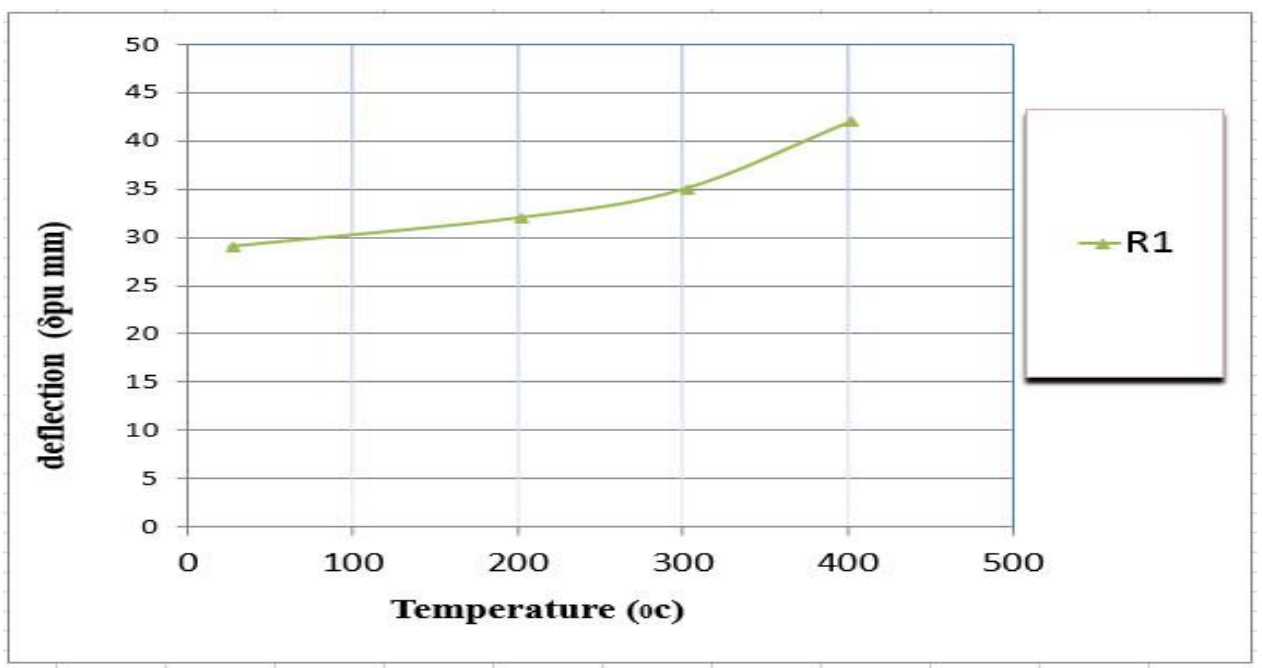

Figure 14. Effect of steel fibers with different volume fractions on mid span Deflection-temperature curve of RPC beams at group 5

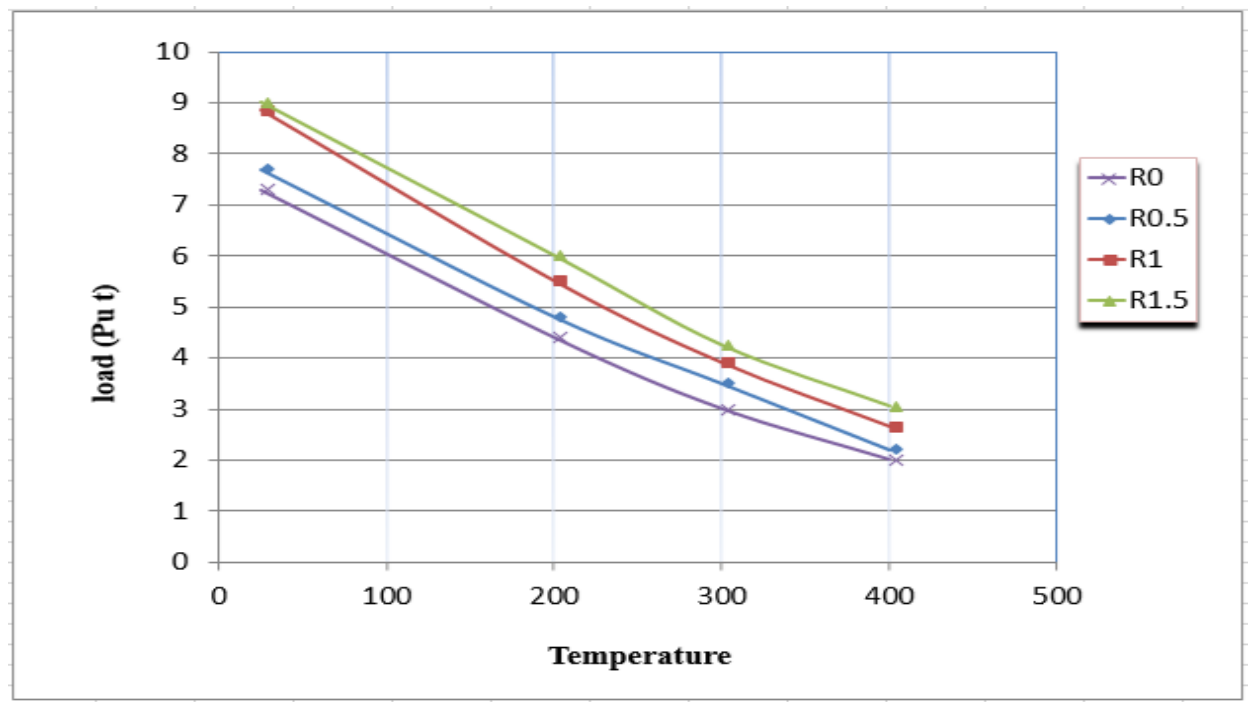

Figure 15. Effect of elevated temperature on ultimate load of RPC beams from group (1-4) 


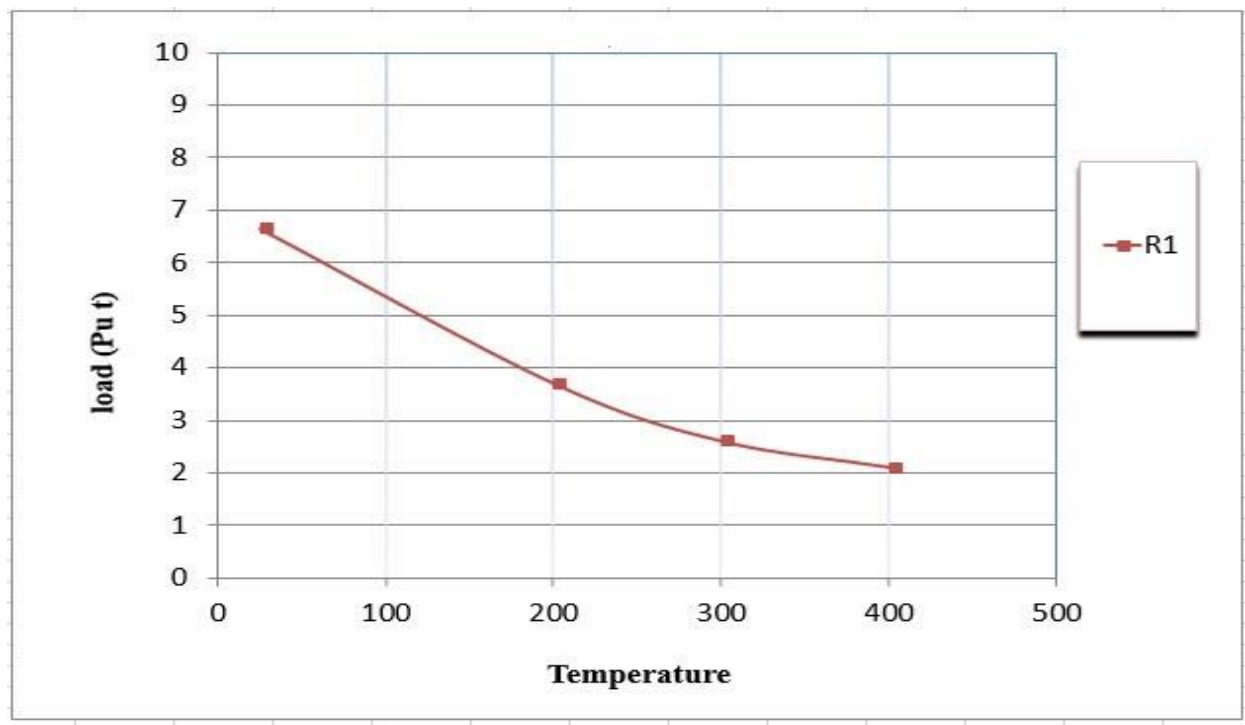

Figure 16. Effect of elevated temperature on ultimate load of RPC beams at group (5)

\section{Conclusions}

According to the experiments presented in this research, the following can be concluded:

1- Reactive powder concrete is the product of a new generation of high-performance concrete.

2- The proportion of steel fibers increases the overall compressive strength.

3- In the final loading stage, as the fiber content increases, the final deflection of the beams will be reduced.

4- After conducting the test, it was found that increasing the proportion of steel fibers in percentages $0.5 \%, 1 \%$ and $1.5 \%$ decreases the mid-span deflection at service load by $33 \%, 50 \%$ and 37.5 and increases the ultimate load by $36.36 \%$, $41.6 \%$ and $53 \%$ respectively.

5- Two types of cracks appeared after the beams were exposed to direct fire, the first type was in the form of honeycomb, and the second type was the result of deflection resulting from bending.

6- Concerning the color of the concrete, the color of the concrete did not change until $200{ }^{\circ} \mathrm{C}$, while notice the color change at higher temperatures, the pink color.

\section{References}

[1] Abdelrahim, Mahmoud Ahmed Ali, Aboelwafa Elthakeb, Usama Mohamed, and Mohamed Taha Noaman. "Effect of steel fibers and temperature on the mechanical properties of reactive powder concrete." Civil and Environmental Engineering 17, no. 1 (2021): 270-276.

[2] Abid, Muhammad, Xiaomeng Hou, Wenzhong Zheng, and Raja Rizwan Hussain. "Effect of fibers on high-temperature mechanical behavior and microstructure of reactive powder concrete." Materials 12, no. 2 (2019): 329.

[3] Mundhada, Ashok R., and Arun D. Pophale. "Effect of elevated temperatures on performance of RCC beams." International Journal of Civil, Structural, Environmental and Infrastructure, Engineering Research and Development 3, no. 3 (2013): 105-112.

[4] Hou, Xiaomeng, Pengfei Ren, Qin Rong, Wenzhong Zheng, and Yao Zhan. "Effect of fire insulation on fire resistance of hybrid-fiber reinforced reactive powder concrete beams." Composite Structures 209 (2019): 219-232.

[5] Kahanji, Charles, Faris Ali, and Ali Nadjai. "Explosive spalling of ultra-high performance fibre reinforced concrete beams under fire." Journal of Structural Fire Engineering (2016), 7, 328-348.

[6] Bayan S. A., Nura, J.M., Residual Strengths of Reinforced Normal Strength, High Strength, Lightweight Concrete Panels Exposed to High Temperatures, Journal of Engineering and Development, 19 (3), 2012, P.190-210.

[7] Aamer, N. A. "Experimental study of polypropylene fiber reinforced concrete panels subjected to elevated temperatures." Journal of Engineering and Development 14, no. 2 (2010): $110-126$

[8] Husem, Metin. "The effects of high temperature on compressive and flexural strengths of 
ordinary and high-performance concrete." Fire Safety Journal 41, no. 2 (2006): 155-163.

[9] Bakhtiyari, S., A. Allahverdi, M. Rais-Ghasemi, A. A. Ramezanianpour, T. Parhizkar, and B. A. Zarrabi. "Mix design, compressive strength and resistance to elevated temperature $(500 \mathrm{C})$ of self-compacting concretes containing limestone and quartz fillers." International Journal of Civil Engineering 9, no. 3 (2011): 215-222.

[10] Anand, N., and G. Prince Arulraj. "Effect of grade of concrete on the performance of selfcompacting concrete beams subjected to elevated temperatures." Fire Technology 50, no. 5 (2014): 1269-1284.

[11] Egyptian Standards-Building Materials Committee "Cement part1: composition, specifications and conformity criteria for common cements (ES 4756- 1)," Cairo (Egypt), Egyptian Organization for Standards and Quality, EOS. 2013.

[12] E.S.S.1109/2008. Aggregates for Concrete. Ministry of Industry, Cairo, Egypt, 2008.

[13] ASTM.C-494. Chemical Admixtures for Concrete. Philadelphia, USA. 2015. 